\title{
Distribution of aerobic anoxygenic phototrophic bacteria in glacial lakes of northern Europe
}

\author{
Michal Mašín ${ }^{1,2, *}$, Zuzana Čuperová ${ }^{1,2}$, Eva Hojerová ${ }^{1,2}$, Ivette Salka ${ }^{3}$, \\ Hans-Peter Grossart ${ }^{3}$, Michal Koblížek ${ }^{1,2}$
}

${ }^{1}$ Institute of Microbiology CAS, Department of Phototrophic Microorganisms, Algatech, Opatovický mlýn, 37981 Třeboň, Czech Republic

${ }^{2}$ Faculty of Science, University of South Bohemia, Branišovská 31, 37005 České Budějovice, Czech Republic

${ }^{3}$ Leibniz-Institute of Freshwater Ecology and Inland Fisheries, Alte Fischerhuette 2, Stechlin 16675, Germany

\begin{abstract}
Glacial lakes cover large areas of northern Europe and North America. These freshwater systems represent important habitats accommodating diverse microbial communities. Here, 27 lakes in northern Germany, Poland and Finland were surveyed for the presence of aerobic anoxygenic phototrophic (AAP) bacteria during the summer seasons of 2008 and 2009. Using infrared epifluorescence microscopy, AAP bacteria were found to represent from 2 to $12 \%$ of total bacteria in surface layers of the studied lakes. The AAP abundance was correlated with total bacterial numbers, total phosphorus and chlorophyll concentration. The size fractionation analyses indicated that a significant portion of AAP cells was attached to particles. Our findings suggest that AAP bacteria represent a significant component of the microbial community in the studied lakes.
\end{abstract}

KEY WORDS: Lakes - Aerobic photosynthetic bacteria $\cdot$ AAP bacteria $\cdot$ Bacteriochlorophyll $a$. Photoheterotrophy

Resale or republication not permitted without written consent of the publisher

\section{INTRODUCTION}

In oxygenic photosynthesis, chlorophyll (chl)containing phytoplankton utilize light energy to assimilate carbon dioxide, and molecular oxygen is evolved. Apart from oxygenic algae and cyanobacteria, there exists a broad phylogenetic spectrum of anoxygenic (non-oxygen evolving) photosynthetic bacteria containing bacteriochlorophyll (BChl). While the majority of anoxygenic phototrophs grow and photosynthesize only under anaerobic conditions, some anoxygenic groups have adapted to aerobic conditions. Such organisms, so-called aerobic anoxygenic phototrophic (AAP) bacteria, were first discovered in Tokyo Bay, Japan (Harashima et al. 1978, Shiba et al. 1979). AAP bacteria are photoheterotrophic organisms, which utilize dissolved organic carbon and harvest light using bacteriochlorophyll a ( $\mathrm{BChl}$ a)-containing reaction centers to supplement their energy requirements (Yurkov \& Csotonyi 2009, Koblížek 2011). AAP bacteria are widely distributed in the marine environment, representing ca. 1.5 to $5 \%$ of total bacteria in the euphotic zone of the oceans (Kolber et al. 2001, Sieracki et al. 2006, Jiao et al. 2007, Koblížek 2011). Moreover, AAP bacteria have also been detected in shelf seas (Koblížek et al. 2005, Mašín et al. 2006, Zhang \& Jiao 2007) and river estuaries (Waidner \& Kirchman 2007, Cottrell et al. 2010). In spite of their low numbers, AAP bacteria seem to be a very dynamic part of the marine bacterial community and contribute significantly to the cycling of organic carbon (Koblížek et al. 2007, Ferrera et al. 2011). 
Despite the increasing amount of data on the distribution, activity and phylogenetic composition of AAP bacteria in marine environments, information on their occurrence in freshwater habitats is still limited. The first freshwater AAP species were isolated from alkaline mat surfaces by Yurkov \& Gorlenko (1990, 1992). Later, the presence of AAP species in limnic habitats was documented by the isolation of several AAP bacteria strains from various freshwater lakes (Page et al. 2004, Gich \& Overmann 2006). The existence of freshwater AAP species was also proven using culture-independent techniques. Anoxygenic photosynthetic genes were found in a fosmid library constructed from Delaware River planktonic DNA (Waidner \& Kirchman 2005) as well as in Swedish lake bacterioplankton (Eiler et al. 2009). A single-cell genomics study documented the presence of AAP species in freshwater lakes in Wisconsin and Maine (Martinez-Garcia et al. 2012). A large survey of Czech lakes (central Europe) finally confirmed the widespread presence of AAP bacteria in a variety of freshwater habitats (Mašín et al. 2008). AAP bacteria were more abundant in oligotrophic and mesotrophic lakes (4 to $21 \%$ ) than in more eutrophic water bodies, where they represented a negligible part of the total microbial community $(<1 \%)$. In the mountain lakes Čertovo and Plešné, AAP bacteria contribute more than one half of the total bacterial biomass during their summer maximum, suggesting that environmental conditions favor the growth of AAP bacteria in these lakes (Mašín et al. 2008). Yet, more systematic studies on the occurrence and distribution of AAP bacteria in a variety of freshwater environments with variable environmental conditions are missing.

Glacial lakes are widely distributed and are the dominant lake type in northern Europe and North America. They vary greatly in size, extending from small pools to major lake systems, such as the North American Great Lakes. Glacial lakes were formed during the retreat of the continental ice sheet after the last ice age ( 10000 yr ago). They are variable in their physicochemical characteristics and therefore represent heterogeneous and dynamic aquatic habitats with large variations in the composition and activities of planktonic bacterial communities. This represents a useful test field for the investigation of AAP distribution and ecology.

Thus, in the present study, we surveyed the AAP abundance and their relative proportion in bacterioplankton communities in glacial lakes in northern Germany, Poland and Finland to establish the main driving factors determining the existence of AAP bacteria in these habitats. In addition, we briefly dis- cuss the potential benefits of phototrophy in AAP bacteria and the relationship between their abundance and lake trophic level.

\section{MATERIALS AND METHODS}

\section{Sampling}

Lakes of the Mecklenburg Lake District, Germany (Tables 1 \& 2), were studied during 2 sampling campaigns (from 10 to 16 June 2008 and from 1 to 18 July 2009). The Mazurian lakes in Poland and lakes in the Lahti region, Finland (Tables 1 \& 2), were sampled on 30 May 2008 and from 1 to 15 July 2008, respectively. Water samples were collected at variable depth with a 21 Friedinger sampler and kept in a plastic cooler in the dark until analysis in the lab. Fluorescence analyses were performed within $2 \mathrm{~h}$ after sample collection. Samples for microscopy were fixed with $37 \%$ formaldehyde $(0.2 \mu \mathrm{m}$ prefiltered, $2 \%$ final concentration) and then stored at $+4{ }^{\circ} \mathrm{C}$ in the dark. All collected samples were processed within 2 mo.

\section{Infrared fluorometry}

Infrared (IR) kinetic fluorometry was performed using a P.S.I. fluorometer control unit (FL200/PS, Photon Systems Instruments) and custom-made optics, as described earlier (Koblížek et al. 2007). For a separation of the chlorophyll and bacteriochlorophyll signal, we used the herbicide Diuron, which selectively removes the chlorophyll fluorescence of phytoplankton (Koblížek et al. 2005). The instrument calibration was performed using a diluted culture of Roseobacter sp. COL2P (Koblížek et al. 2010). The instrument sensitivity was sufficient for processing of natural water samples with an absolute detection limit of $0.2 \mathrm{ng} \mathrm{BChl} \mathrm{a} \mathrm{l}^{-1}$ and $3 \mathrm{ng}$ chl $a \mathrm{l}^{-1}$ and a relative detection limit of ca. $10^{-3}$ $\mathrm{BChl}$ a to chl a ratio.

\section{Microscopy}

IR epifluorescence microscopy analyses were performed as described previously (Mašín et al. 2006). Briefly, the collected water samples were filtered onto a $0.2 \mu \mathrm{m}$ polycarbonate filter (Nucleopore, Whatman), dried, stained with DAPI and mounted on microscopic glass slides. Microscopy was performed using a fluorescence Olympus BX51TF 
Table 1. Studied lakes. GER: Germany, PL: Poland, FIN: Finland

\begin{tabular}{|c|c|c|c|c|c|c|}
\hline Name & Country & $\begin{array}{c}\text { Area } \\
\text { (ha) }\end{array}$ & $\begin{array}{l}\text { Maximum } \\
\text { depth (m) }\end{array}$ & Trophic status & Latitude & Longitude \\
\hline Breiter Luzin & GER & 357 & 58.5 & Mesotrophic & $53^{\circ} 21^{\prime} \mathrm{N}$ & $13^{\circ} 27^{\prime} \mathrm{E}$ \\
\hline Carwitzer & GER & 722 & 42.2 & Mesotrophic & $53^{\circ} 18^{\prime} \mathrm{N}$ & $13^{\circ} 27^{\prime} \mathrm{E}$ \\
\hline Dagow & GER & 23 & 8.0 & Mesotrophic & $53^{\circ} 09^{\prime} \mathrm{N}$ & $13^{\circ} 03^{\prime} \mathrm{E}$ \\
\hline Dollgow & GER & 18 & 2 & Eutrophic & $53^{\circ} 04^{\prime} \mathrm{N}$ & $13^{\circ} 00^{\prime} \mathrm{E}$ \\
\hline G. Fuchskuhle NW & GER & 2 & 5.6 & Eutrophic & $53^{\circ} 10^{\prime} \mathrm{N}$ & $13^{\circ} 02^{\prime} \mathrm{E}$ \\
\hline G. Fuchskuhle SE & GER & 2 & 5.6 & Eutrophic & $53^{\circ} 10^{\prime} \mathrm{N}$ & $13^{\circ} 02^{\prime} \mathrm{E}$ \\
\hline Haus & GER & 136 & 12.0 & Meso-eutrophic & $53^{\circ} 10^{\prime} \mathrm{N}$ & $13^{\circ} 14^{\prime} \mathrm{E}$ \\
\hline Nehmitz North & GER & 98 & 18.6 & Mesotrophic & $53^{\circ} 08^{\prime} \mathrm{N}$ & $12^{\circ} 59^{\prime} \mathrm{E}$ \\
\hline Nehmitz South & GER & 62 & 18.6 & Mesotrophic & $53^{\circ} 07^{\prime} \mathrm{N}$ & $12^{\circ} 58^{\prime} \mathrm{E}$ \\
\hline Peetsch & GER & 89 & 21.5 & Oligotrophic & $53^{\circ} 10^{\prime} \mathrm{N}$ & $13^{\circ} 04^{\prime} \mathrm{E}$ \\
\hline Roofen & GER & 57 & 19.1 & Mesotrophic & $53^{\circ} 06^{\prime} \mathrm{N}$ & $13^{\circ} 02^{\prime} \mathrm{E}$ \\
\hline Schmaler Luzin & GER & 129 & 34 & Mesotrophic & $53^{\circ} 19^{\prime} \mathrm{N}$ & $13^{\circ} 26^{\prime} \mathrm{E}$ \\
\hline Stechlin & GER & 430 & 68.0 & Oligotrophic & $53^{\circ} 09^{\prime} \mathrm{N}$ & $13^{\circ} 01^{\prime} \mathrm{E}$ \\
\hline Stolp & GER & 421 & 12.0 & Eutrophic & $53^{\circ} 10^{\prime} \mathrm{N}$ & $13^{\circ} 12^{\prime} \mathrm{E}$ \\
\hline Tiefwaren & GER & 140 & 24 & Mesotrophic & $53^{\circ} 31^{\prime} \mathrm{N}$ & $12^{\circ} 41^{\prime} \mathrm{E}$ \\
\hline Wittwe & GER & 160 & 13 & Oligo-mesotrophic & $53^{\circ} 07^{\prime} \mathrm{N}$ & $12^{\circ} 56^{\prime} \mathrm{E}$ \\
\hline Głębokie & PL & 47 & 34.3 & Eutrophic & $53^{\circ} 48^{\prime} \mathrm{N}$ & $21^{\circ} 30^{\prime} \mathrm{E}$ \\
\hline Kuc & PL & 99 & 28.8 & Mesotrophic & $53^{\circ} 49^{\prime} \mathrm{N}$ & $21^{\circ} 24^{\prime} \mathrm{E}$ \\
\hline Kruczy Staw & PL & 2 & 8.0 & Oligo-dystrophic & $53^{\circ} 40^{\prime} \mathrm{N}$ & $21^{\circ} 24^{\prime} \mathrm{E}$ \\
\hline Majcz & PL & 45 & 16.5 & Mesotrophic & $53^{\circ} 46^{\prime} \mathrm{N}$ & $21^{\circ} 27^{\prime} \mathrm{E}$ \\
\hline Mikołajskie & $\mathrm{PL}$ & 498 & 25.9 & Eutrophic & $53^{\circ} 46^{\prime} \mathrm{N}$ & $21^{\circ} 35^{\prime} \mathrm{E}$ \\
\hline Tałtowisko & PL & 327 & 39.5 & Eutrophic & $53^{\circ} 52^{\prime} \mathrm{N}$ & $21^{\circ} 34^{\prime} \mathrm{E}$ \\
\hline Zełwążek & PL & 12 & 7.4 & Eutrophic & $53^{\circ} 49^{\prime} \mathrm{N}$ & $21^{\circ} 30^{\prime} \mathrm{E}$ \\
\hline Alasen & FIN & 286 & 15 & Oligo-mesotrophic & $61^{\circ} 00^{\prime} \mathrm{N}$ & $25^{\circ} 44^{\prime} \mathrm{E}$ \\
\hline Jout & FIN & 40 & 2.5 & Mesotrophic & $60^{\circ} 58^{\prime} \mathrm{N}$ & $25^{\circ} 41^{\prime} \mathrm{E}$ \\
\hline Merras & FIN & 26 & 5.0 & Mesotrophic & $61^{\circ} 00^{\prime} \mathrm{N}$ & $25^{\circ} 41^{\prime} \mathrm{E}$ \\
\hline Mytäjäinen & FIN & 2 & 11.0 & Mesotrophic & $60^{\circ} 58^{\prime} \mathrm{N}$ & $25^{\circ} 38^{\prime} \mathrm{E}$ \\
\hline Orma & FIN & 650 & 31.0 & Mesotrophic & $61^{\circ} 05^{\prime} \mathrm{N}$ & $24^{\circ} 58^{\prime} \mathrm{E}$ \\
\hline Vesi & FIN & 11000 & 42.0 & Meso-eutrophic & $61^{\circ} 00^{\prime} \mathrm{N}$ & $25^{\circ} 36^{\prime} \mathrm{E}$ \\
\hline
\end{tabular}

microscope equipped with a B/W CCD camera (FViewII). Total DAPI-stained bacteria were recorded in the blue part of the spectrum (50 to $200 \mathrm{~ms}$ exposure), and then the IR emission image was captured, detecting both AAP bacteria and phytoplankton (30 s exposure). Finally, red chl a autofluorescence was recorded to identify chl a-containing organisms (200 to $500 \mathrm{~ms}$ exposure). The acquired images were saved and semi-manually analyzed using the AnalySIS software (Soft Imaging Solutions). The abundance of total and AAP bacteria was quantified in terms of cell numbers.

\section{Chlorophyll, nutrient and carbon analyses}

Chl a was determined by spectrophotometry in $90 \%$ acetone extracts (Lorenzen 1967). Water samples from each lake were analyzed for total phosphorus (TP), soluble reactive phosphorus (SRP/ $\mathrm{PO}_{4}{ }^{3-}$ ), total nitrogen (TN), nitrate $\left(\mathrm{NO}_{3}{ }^{-}\right)$and nitrite $\left(\mathrm{NO}_{2}{ }^{-}\right)$ as well as ammonia $\left(\mathrm{NH}_{4}\right)$ and dissolved organic car- bon (DOC) levels. Briefly, after filtration through $0.2 \mu \mathrm{m}$ pre-rinsed polycarbonate filter (Whatman), $\mathrm{PO}_{4}{ }^{3-}$ was photometrically measured with an FIAcompact (MLE) using the molybdenum blue method described by Koroleff (1976). TP was first digested to SRP with $\mathrm{K}_{2} \mathrm{~S}_{2} \mathrm{O}_{3}\left(134^{\circ} \mathrm{C}\right.$ for $\left.30 \mathrm{~min}\right)$ and then determined as $\mathrm{PO}_{4}{ }^{3-}$. To determine nitrite, nitrate and ammonia levels, water samples were first filtered through pre-rinsed $0.2 \mu \mathrm{m}$ cellulose acetate filters (Whatman) and photometrically analyzed with a FIAstar $^{\mathrm{TM}} 5010$ analyzer (FOSS) using standard protocols (Wetzel \& Likens 1991) and the manufacturer's instructions. Total nitrogen was first digested to $\mathrm{NO}_{3}{ }^{-} / \mathrm{NO}_{2}{ }^{-}$with an Oxisolv ${ }^{\circledR}$ (Merck) treatment and allowed to react at $120^{\circ} \mathrm{C}$ for $45 \mathrm{~min}$. Dissolved organic carbon (DOC) was determined as nonpurgeable organic carbon (NPOC). Water samples were filtered through $0.45 \mu \mathrm{m}$ pre-rinsed cellulose nitrate filters (Whatman) and treated with $2 \mathrm{~N} \mathrm{HCl}$. DOC was then analyzed by high temperature combustion in a TOC analyzer (Multi N/C 3100, Analytik Jena AG). 
Table 2. Basic physicochemical characteristics of Mecklenburg lakes (Germany) sampled in June 2008 and July 2009. TP: total phosphorus, TN: total nitrogen, NPOC: non-purgeable organic carbon, -: no data

\begin{tabular}{|c|c|c|c|c|c|c|c|c|c|c|c|}
\hline & $\begin{array}{c}\text { Temperature } \\
\left({ }^{\circ} \mathrm{C}\right)\end{array}$ & $\mathrm{pH}$ & $\begin{array}{c}\text { Chl a } \\
\left(\mu \mathrm{g} \mathrm{l}^{-1}\right)\end{array}$ & $\begin{array}{l}\text { Total bacteria } \\
\quad\left(10^{6} \mathrm{ml}^{-1}\right)\end{array}$ & $\begin{array}{c}\text { TP } \\
\left(\mu \mathrm{g} \mathrm{l}^{-1}\right)\end{array}$ & $\begin{array}{l}\mathrm{PO}_{4}{ }^{3-} \\
\left(\mu \mathrm{g} \mathrm{l}^{-1}\right)\end{array}$ & $\begin{array}{c}\mathrm{TN} \\
\left(\mathrm{mg} \mathrm{l}^{-1}\right)\end{array}$ & $\begin{array}{c}\mathrm{NH}_{4}^{+} \\
\left(\mu \mathrm{g} \mathrm{l}^{-1}\right)\end{array}$ & $\begin{array}{l}\mathrm{NO}_{2}^{-} \\
\left(\mu \mathrm{g} \mathrm{l}^{-1}\right)\end{array}$ & $\begin{array}{c}\mathrm{NO}_{3}^{-} \\
\left(\mu \mathrm{g} \mathrm{l}^{-1}\right)\end{array}$ & $\begin{array}{c}\mathrm{NPOC} \\
\left(\mathrm{mg} \mathrm{l}^{-1}\right)\end{array}$ \\
\hline \multicolumn{12}{|l|}{ Lakes 2008} \\
\hline Breiter Luzin & 19.4 & 8.56 & 1.56 & 5.84 & 18 & 2 & 0.30 & 35 & 0 & 2 & 13.58 \\
\hline Carwitzer & 19.9 & 8.75 & 1.86 & 4.74 & 13 & 1 & 0.42 & 21 & 0 & 1 & - \\
\hline Dagow & 21.9 & 8.39 & 4.73 & 11.10 & - & - & - & - & - & - & - \\
\hline Dollgow & 22.8 & 8.34 & 35.73 & 15.00 & 67 & 3 & 0.73 & 36 & 3 & 28 & - \\
\hline G. Fuchskuhle NW & 22.5 & 6.14 & 5.20 & 7.11 & 32 & 2 & 0.58 & 36 & 3 & 13 & - \\
\hline G. Fuchskuhle SE & 21.6 & 6.00 & 6.29 & 9.38 & 16 & 5 & 0.78 & 164 & 4 & 58 & \\
\hline Haus & 20.2 & 8.64 & 11.81 & 16.70 & 44 & 4 & 0.91 & 36 & 0 & 14 & 23.90 \\
\hline Nehmitz North & 21.7 & 8.40 & 1.00 & 5.71 & 17 & 1 & 0.35 & 35 & 0 & 15 & - \\
\hline Nehmitz South & 21.9 & 8.48 & 5.71 & 6.24 & 9 & $<1$ & 0.41 & 38 & 5 & 21 & - \\
\hline Peetsch & 19.4 & 9.00 & 1.97 & 4.28 & 10 & $<1$ & 0.53 & 35 & 2 & 28 & - \\
\hline Roofen & 22.2 & 8.45 & 1.60 & 6.09 & 15 & 1 & 1.06 & 36 & 7 & 296 & - \\
\hline Schmaler Luzin & 19.9 & 8.56 & 4.71 & 5.68 & 20 & 4 & 0.45 & 7 & 0 & 7 & - \\
\hline Stechlin & 20.4 & 8.70 & 0.86 & 3.09 & 11 & $<1$ & 0.29 & 10 & 2 & 23 & 10.64 \\
\hline Stolp & 19.8 & 8.60 & 13.48 & - & - & $<1$ & 0.74 & 36 & 2 & 16 & - \\
\hline Tiefwaren & 18.8 & 8.62 & 3.08 & 5.37 & 24 & 1 & 0.66 & 38 & 5 & 200 & 18.72 \\
\hline Wittwe & 21.8 & 8.72 & 1.81 & 4.03 & 15 & 1 & 0.48 & 36 & 2 & 16 & - \\
\hline \multicolumn{12}{|l|}{ Lakes 2009} \\
\hline Breiter Luzin & 21.6 & 8.87 & 4.00 & 2.93 & 21 & 2 & 0.55 & 13 & 0 & 13.16 & 7.70 \\
\hline Dagow & - & - & - & 6.27 & 27 & 2 & 0.97 & 24 & 0 & 9.70 & 12.06 \\
\hline Dollgow & 21.5 & 8.65 & 21.05 & 15.24 & 81 & 10 & 0.86 & 30 & 0 & 7.86 & 9.37 \\
\hline G. Fuchskuhle NW & 23.0 & 6.30 & 14.40 & 3.61 & 29 & 4 & 2.95 & 24 & 1.15 & 3.45 & 16.30 \\
\hline G. Fuchskuhle SE & 22.5 & 7.74 & 12.70 & 3.86 & 25 & 3 & 1.24 & 77 & 0 & 13.00 & 15.32 \\
\hline Haus & 23.5 & 8.64 & 15.88 & 7.44 & 33 & 6 & 1.70 & 6 & 0 & 7.20 & 15.57 \\
\hline Nehmitz North & 21.8 & 8.40 & 1.03 & 3.05 & 13 & 4 & 0.65 & 16 & 0 & 19.60 & 7.68 \\
\hline Peetsch & 19.8 & 8.50 & 1.28 & 3.53 & 10 & 7 & 0.69 & 67 & 0 & 8.80 & 9.93 \\
\hline Roofen & 20.6 & 8.40 & 3.88 & 4.60 & 14 & $<1$ & 0.76 & 75 & 8.70 & 255.40 & 6.44 \\
\hline Schmaler Luzin & 20.8 & 8.80 & 2.00 & 3.88 & 15 & $<1$ & 0.48 & 28 & 0 & 5.00 & - \\
\hline Stechlin & 21.2 & 8.85 & 0.93 & 2.82 & 13 & 2 & 0.53 & 37 & 0 & 35.40 & 7.82 \\
\hline Stolp & 21.1 & 8.86 & 11.62 & 9.93 & 44 & 3 & 1.07 & 19 & 0 & 14.40 & 11.49 \\
\hline Tiefwaren & 22.5 & 8.96 & 5.00 & - & 18 & 2 & 0.75 & 17 & 0 & 36.10 & 9.53 \\
\hline Wittwe & 21.3 & 8.82 & 1.55 & 4.82 & 11 & 3 & 0.65 & 7 & 0 & 7.86 & 8.32 \\
\hline
\end{tabular}

\section{RESULTS}

\section{Vertical distribution of $\mathrm{BChl}$ a signal}

The distribution of AAP bacteria was surveyed in 14 glacial lakes in the Mecklenburg Lake District (north-eastern Germany) during 2 sampling campaigns in June 2008 and July 2009. The lakes greatly differed in their physicochemical characteristics and trophic status (Tables $1 \& 2$ ). Only lakes Stechlin and Peetsch were oligotrophic, whereas all of the other studied lakes were either mesotrophic or eutrophic. In addition, Grosse Fuchskuhle is a dystrophic lake because the major water inflow is via a bog area (Hutalle-Schmelzer et al. 2010). In the early 1990s, the lake was experimentally divided into 4 sections, which greatly differ in their chemical parameters.

In contrast to predominantly aerobic marine environments, in freshwater lakes, we frequently en- counter an anoxic part of the water column. This fact complicates the detection of AAP bacteria because there is no convenient optical method that could discriminate between mostly anaerobic purple phototrophic bacteria and AAP bacteria. For this reason, the vertical oxygen profiles were recorded for all of the German lakes sampled. Several of these lakes had a narrow anoxic hypolimnion above the bottom (Fuchskuhle, Dagow, Nehmitz, Roofen). The sole lake with a well-developed anaerobic layer in both sampling seasons was Lake Haus.

As an example, we recorded the vertical distribution of BChl a using IR kinetic fluorometry in oligotrophic Lake Stechlin (an aerobic lake), mesotrophic Lake Roofen (aerobic epilimnion and anaerobic hypolimnion) and in eutrophic Lake Haus (mostly anoxic). In Lake Stechlin, the highest BChl a concentration was measured at the surface and gradually decreased with depth (Fig. 1A). A second 

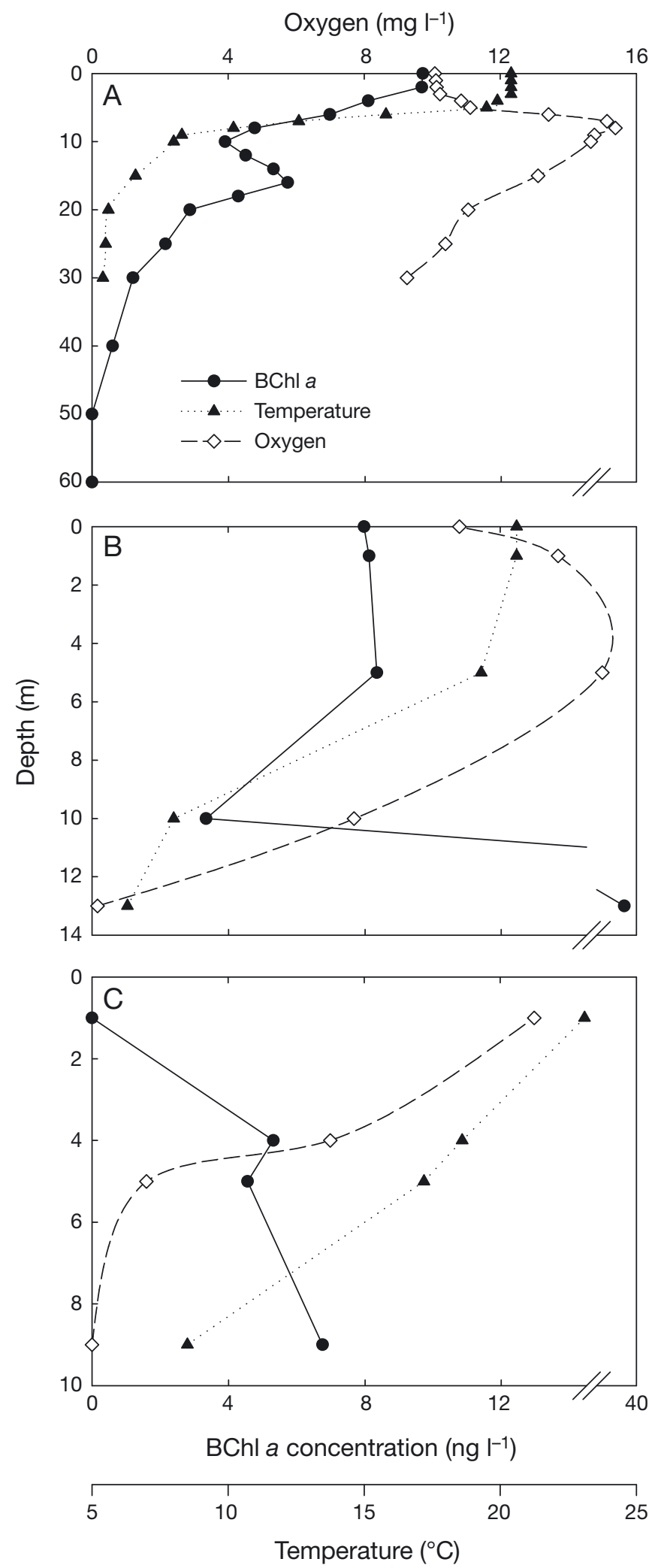

Fig. 1. Depth profiles from (A) Lake Stechlin, 17 June 2008, (B) Lake Roofen, 11 July 2009, and (C) Lake Haus, 8 July 2009. Bacteriochlorophyll a (BChl a) concentrations were estimated by IR kinetic fluorometry
BChl a peak was detected below the thermocline at $18 \mathrm{~m}$ depth, overlapping with a deep Chl a maximum formed by picoeukaryotes and cyanobacteria (data not shown). Measurements of dissolved oxygen confirmed that Lake Stechlin was aerobic throughout the whole water column. In Lake Roofen, 2 BChl a zones were detected in the water column. These zones were separated by the thermocline (Fig. 1B), which suggests that 2 different populations of phototrophic bacteria were present in the oxic epilimnion and in the anaerobic part of the hypolimnion. In the shallow (max. depth $9 \mathrm{~m}$ ) and more eutrophic Lake Haus, the BChl a concentration was the highest at the bottom, while no BChl a was detected at the surface. Lake Haus was well stratified, and the lower part of the hypolimnion was fully anaerobic, suggesting that this lake was inhabited by mainly anaerobic phototrophic bacterial species (Fig. 1C).

Based on the observed vertical profiles, the water samples for further study were always collected from the fully aerobic subsurface layers ( $0.3 \mathrm{~m}$ depth) to ensure that the registered signals originate predominantly from AAP species and to ensure comparable sampling conditions in all of the studied lakes.

\section{Lake survey}

Based on IR fluorometry, BChl a concentrations in the Mecklenburg lakes varied from 1 to $40 \mathrm{ng} \mathrm{BChl} \mathrm{a}$

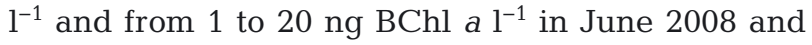
July 2009, respectively (Fig. 2). In most of the lakes, the $\mathrm{BChl}$ a concentration differed between the 2 sampling campaigns. An extreme case was Lake Haus, showing the highest $\mathrm{BChl}$ a concentration out of all surveyed lakes in 2008 (40 ng $\left.^{-1}\right)$, whereas no BChl a could be detected in 2009 (Fig. 2A,B).

During the 2008 campaign, AAP bacterial abundances ranged from $1 \times 10^{5}$ to $12 \times 10^{5}$ cells ml ${ }^{-1}$ and contributed on average $6.0 \pm 2.6 \%$ of the total bacteria (Fig. 2A). The highest proportion of AAP bacteria $(12 \%)$ was detected in oligotrophic Lake Stechlin, whereas the lowest AAP bacteria abundance and proportion $(2.2 \%$ of total bacteria) was found in mesotrophic Lake Tiefwaren. A slightly higher proportion of AAP bacteria was found in 2009, ranging from 3.2 to $12.0 \%(8.0 \pm 2.6 \%$, mean $\pm \mathrm{SD}, \mathrm{n}=13)$. Interestingly, the proportion of AAP bacteria found in Lake Stechlin was much lower $(5.6 \%)$ than in the previous year.

Both the AAP abundances and total bacterial abundances correlated well with the overall trophic 


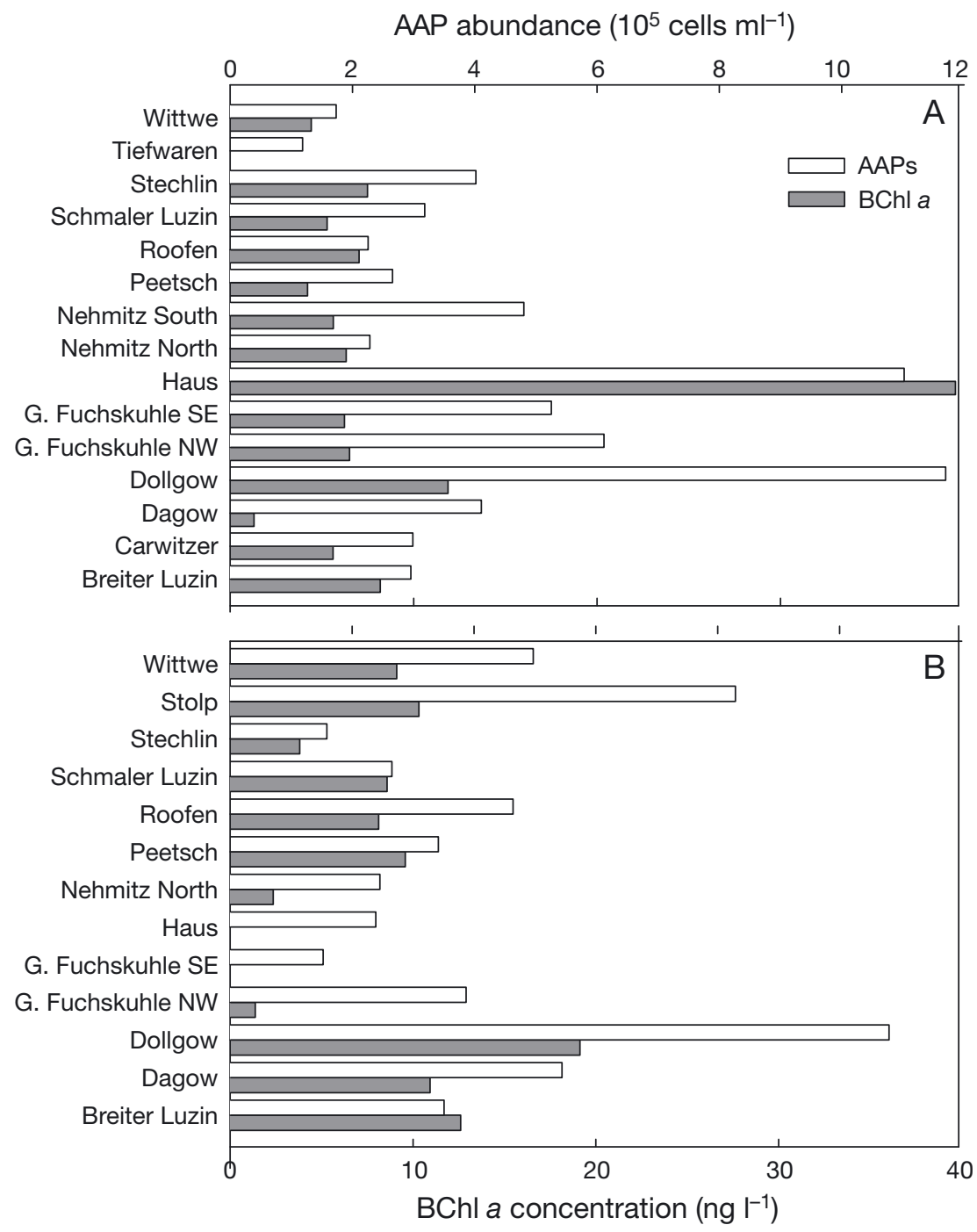

Fig. 2. Abundance of AAP bacteria and BChl a concentration in lakes of the Mecklenburg Lake District. AAP bacteria were determined by IR epifluorescence microscopy; $\mathrm{BChl}$ a concentration was estimated from IR fluorescence measurement. Panel A reports results from June 2008 campaign; Panel B from July 2009 abundance was also positively correlated with BChl a concentration (Table 3). Thus, AAP bacteria abundance generally increased in lakes with higher trophic status; however, there was no correlation between AAP percentage and total phosphorus (Pearson, $\mathrm{r}=-0.02, \mathrm{p}=0.907$, $\mathrm{n}=27)$. The correlation between AAP abundance and temperature observed previously during seasonal studies (Mašín et al. 2006, 2008) was not observed in our dataset (see Table 3), most likely due to the relatively small span of surface temperatures $\left(21.2 \pm 1.2^{\circ} \mathrm{C}\right.$, mean $\left.\pm \mathrm{SD}\right)$ encountered in the sampled lakes.

In addition to the Mecklenburg Lake District, we also surveyed several lakes of the Mazurian Lake District, Poland, and several lakes in the Lahti region, Finland, in summer 2008. The absolute and relative AAP abundances in Polish and Finnish lakes were similar to those found in the Mecklenburg Lake District. In the Mazurian lakes, AAP abundances ranged from $1.6 \times 10^{5}$ to 5.2 $\times 10^{5}$ cells $\mathrm{ml}^{-1}$, which represented 2.1 to $4.9 \%$ of the total bacteria. In Finnish lakes, AAP made up $1.6 \times$ $10^{5}$ to $5.5 \times 10^{5}$ cells $\mathrm{ml}^{-1}$, which represented 3.7 to $8.2 \%$ of total bacteria (Fig. 4). The BChl a concentration in the Mazurian lakes (Poland) ranged from 5 to $24 \mathrm{ng} \mathrm{BChl} \mathrm{a} \mathrm{l}^{-1}$ in May 2008. status of the lakes for both campaigns individually as well as for the merged dataset. Based on statistical analyses, it seems that the major structuring factor was total phosphorus content (Fig. 3), which was strongly positively correlated (merged dataset) with chlorophyll concentration (Pearson, $r=0.863$, $\mathrm{p}<0.0001, \mathrm{n}=26$ ), total bacterial abundances (Pearson, $\mathrm{r}=0.833, \mathrm{p}<0.0001, \mathrm{n}=27$ ) and AAP abundances (Pearson, $\mathrm{r}=0.799, \mathrm{p}<0.0001, \mathrm{n}=27$ ). This observation is consistent with the general dissolved reactive phosphorus-limited character of the studied lakes. No correlation was found between total nitrogen or dissolved organic carbon (NPOC) and any of the above-mentioned parameters. AAP

\section{Size fractionation of the BChl a signal}

A size fractionation study of collected samples was conducted to determine the approximate size of AAP cells and fraction of the cells attached to particles. For each lake, we recorded the BChl a fluorescence signal in 3 size fractions: $<0.8 \mu \mathrm{m}, 0.8$ to $5 \mu \mathrm{m}$ and $>5.0 \mu \mathrm{m}$. To avoid retention of larger and more active free-living cells together with particles and organisms, we used a $5 \mu \mathrm{m}$ instead of a $2 \mu \mathrm{m}$ pre-filtration step, which was used by Lami et al. (2009). The filtration of freshly collected samples was carried out solely by gravity to avoid disintegration of larger particles and lasted for no more 


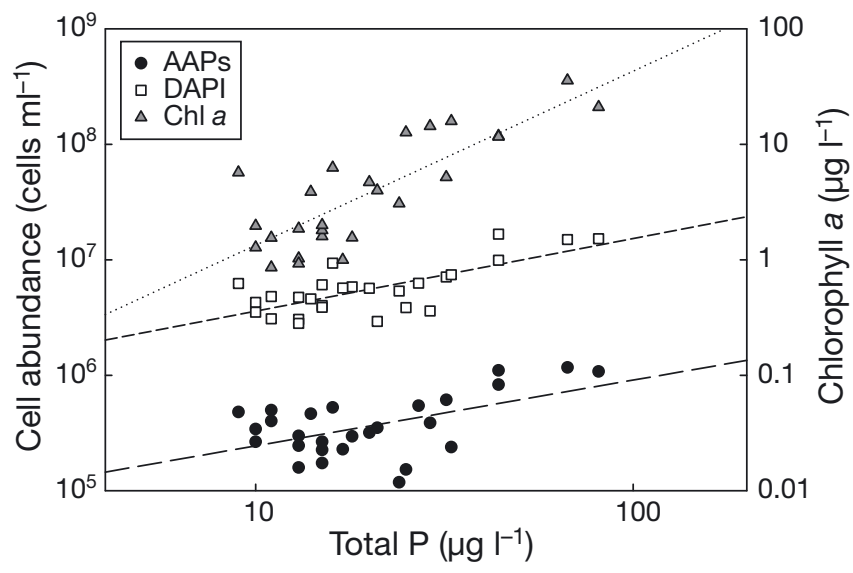

Fig. 3. AAP abundance, total bacterial abundance and chlorophyll concentration versus total phosphorus for Mecklenburg lakes (2008 and 2009). The slopes of log-log plots are $k=0.57$ for AAP abundance, $k=0.63$ for bacterial abundance and $k=1.51$ for chlorophyll

Table 3. Statistical correlations between surface AAP abundances and basic physicochemical and biological parameters for the Mecklenburg lakes (Germany) sampled during 2008 and 2009. Significant correlations $(\alpha=0.05)$ are highlighted in bold. BChl a concentrations were estimated from IR fluorometric measurements. r: Pearson product moment correlation coefficient, $\mathrm{p}$ : associated probability, n: number of samples. The percentages of AAP bacteria were not correlated with any of the parameters (data not shown). NPOC: non-purgeable organic carbon

\begin{tabular}{|lccc|}
\hline \multirow{2}{*}{ Variables } & \multicolumn{3}{c}{ AAP abundance } \\
\cline { 2 - 3 } & $\mathrm{r}$ & $\mathrm{p}$ & $\mathrm{n}$ \\
\hline Temperature & 0.141 & 0.484 & 27 \\
$\mathrm{pH}$ & -0.080 & 0.694 & 27 \\
Total P & $\mathbf{0 . 7 9 9}$ & $<\mathbf{0 . 0 0 0 1}$ & $\mathbf{2 7}$ \\
Total N & 0.066 & 0.745 & 27 \\
NPOC & 0.182 & 0.500 & 16 \\
DAPI & $\mathbf{0 . 8 6 0}$ & $\mathbf{< . 0 0 0 1}$ & $\mathbf{2 8}$ \\
Chl $\boldsymbol{a}$ & $\mathbf{0 . 7 0 8}$ & $\mathbf{< . 0 0 0 1}$ & $\mathbf{2 7}$ \\
BChl $\boldsymbol{a}$ & $\mathbf{0 . 7 3 0}$ & $\mathbf{< 0 . 0 0 0 1}$ & $\mathbf{2 8}$ \\
\hline
\end{tabular}

than 30 min. Samples were divided in triplicate and measured separately to check for variability among individual measurements. Small free-living AAP bacteria $(<0.8 \mu \mathrm{m})$ accounted for 20 to $66 \%$ of the total BChl a signal, whereas the larger free-living AAP bacteria 0.8 to $5 \mu \mathrm{m}$ in size varied between 14 and $42 \%$ of the bulk BChl a signal (Fig. 5). The amount of AAP cells attached to particles and organisms ( $>5 \mu \mathrm{m}$ fraction) varied between 15 and $50 \%$. No significant statistical correlation was found between the size fractions and $\mathrm{BChl} a$ concentration or lake trophic status.

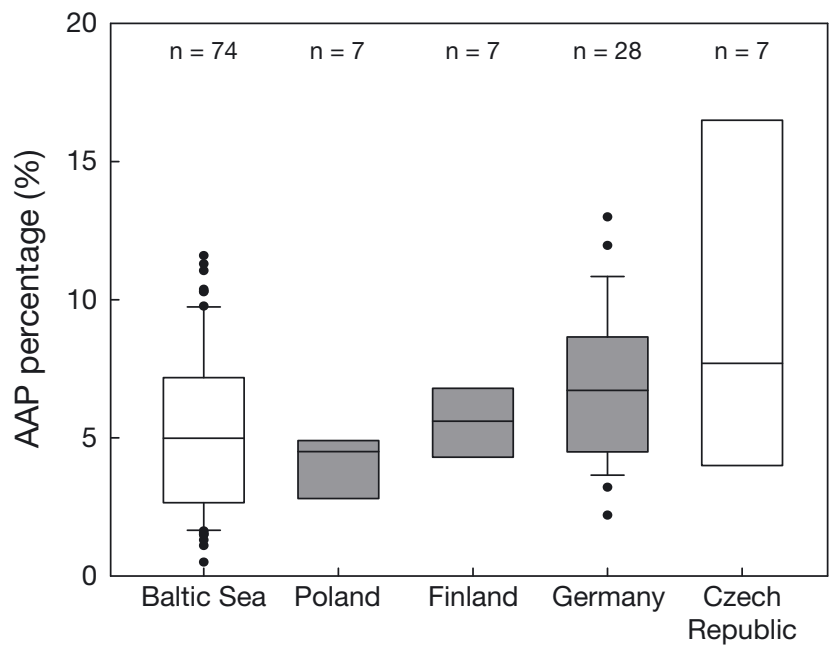

Fig. 4. AAP percentages determined in German, Polish and Finnish lakes in comparison with previous studies from the Baltic Sea (Mašín et al. 2006, Salka et al. 2008) and Czech freshwater lakes (Mašín et al. 2008). The numerals report the sample size; central lines represent the medians, the bottom and top of the box are lower and upper quartiles, the whiskers depict the 5th and 95th percentiles, and the dots represent outlier values

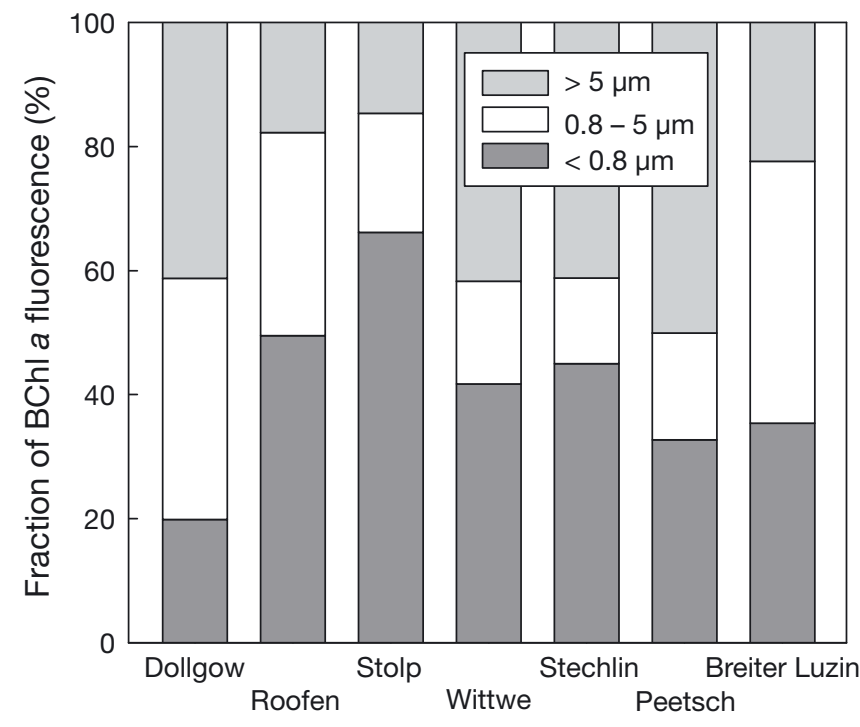

Fig. 5. The distribution of BChl a fluorescence in different size fractions and its variation in lakes of northern Germany during the sampling campaign in 2009

\section{DISCUSSION}

In the present study, we surveyed the occurrence of phototrophic bacteria in a variety of freshwater lakes in the Mecklenburg Lake District (northern Germany), the Mazurian Lake District (Poland) and in southern Finland. The majority of the surveyed 
lakes (northern Germany and Poland) have been the sites of intense long-term limnological research (Koschel 1995, Hillbricht-Ilkowska et al. 2000, Allgaier \& Grossart 2006a,b, Chróst \& Siuda 2006), whereas a few of the Finnish lakes have been studied in a local context only. Our 2 sampling campaigns in 2008 and 2009 revealed that phototrophic bacteria were present in all studied lakes. The AAP abundances recorded during our study ranged from $1.18 \times$ $10^{5}$ to $11.7 \times 10^{5}$ cells ml ${ }^{-1}\left(3.92 \pm 2.54 \times 10^{5}\right.$, mean \pm $\mathrm{SD}, \mathrm{n}=42$ ), which is slightly higher than numbers reported previously from Czech lakes (0.9 to $4.25 \times$ $10^{5}$ cells $\mathrm{ml}^{-1}$ ). The difference might be partially due to the fact that the present study was conducted exclusively in summer months, which is the AAP seasonal maximum, as shown previously (Mašín et al. 2006, 2008). Interestingly, ca. 4-fold higher AAP counts $\left(0.8\right.$ to $60.0 \times 10^{5}$ cells $\left.\mathrm{ml}^{-1}\right)$ were found in saline steppe lakes in Central Asia (Medová et al. 2011), in spite of the fact that the chlorophyll concentrations were comparable to those registered in this

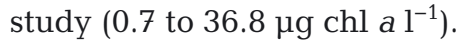

The relative proportion of AAP bacteria ranged between 2 and $12 \%$ of total prokaryotes (Fig. 6). When we cluster the data based on the territory, the highest AAP percentages were found in Mecklenburg lakes $(7.0 \pm 2.8 \%$, mean $\pm \mathrm{SD}, \mathrm{n}=28)$ and Finnish lakes $(5.7 \pm 1.5 \%$, mean $\pm \mathrm{SD}, \mathrm{n}=7)$, whereas the lowest percentages were found in Mazurian lakes $(4.0 \pm 1.1 \%$, mean $\pm \mathrm{SD}, \mathrm{n}=7)$. These values are comparable with previous reports from Czech freshwater lakes (Mašín et al. 2008). Interestingly, the proportion of AAP bacteria observed in the present study is similar to that reported from brackish and coastal waters (Cottrell et al. 2006, Mašín et al. 2006, Sieracki et al. 2006, Zhang \& Jiao 2007, Salka et al. 2008).

An important question arises regarding whether all observed BChl a-containing bacteria were really true AAP species. In contrast to marine environments, the situation in freshwater habitats is complicated by the fact that many lakes contain hypoxic or fully anoxic hypolimnia. Hence, there exists a certain chance that some primarily anaerobic species might enter also the aerobic epilimnion, and one cannot completely rule out the possibility that a part of the BChl apositive cells originate from anaerobic phototrophic species. However, the strong stratification of most of these lakes prevents the mixing of aerobic and anaerobic layers and strongly reduces the possibility of penetration of anaerobic species into the sampled subsurface layer. Another potential source of anaerobic species might be the microbial aggregates or
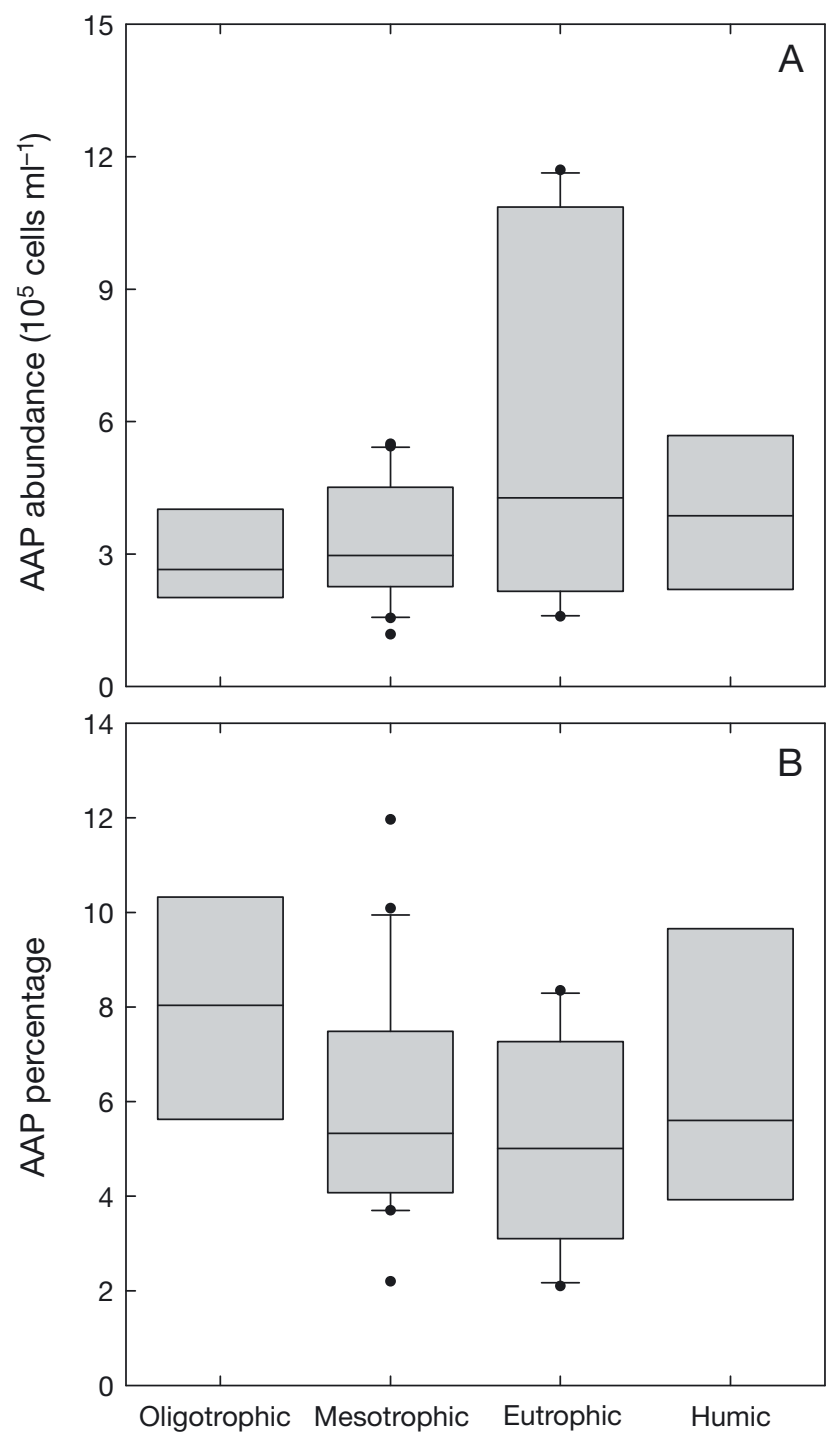

Fig. 6. (A) AAP abundance and (B) percentage of AAP among total prokaryotes determined in oligotrophic, mesotrophic, eutrophic and humic lakes. The lake classification is mostly based on the total phosphorus and chlorophyll concentration as listed in Table 1. Central lines represent the medians; bottom and top of the box are lower and upper quartiles; the whiskers depict the 5th and 95th percentiles, and the dots represent outlier values

flocs, where the oxygen tension might be significantly reduced, but such aggregates have to be relatively large and robust. In contrast, the majority of the observed BChl a signal was associated with the $<5 \mu \mathrm{m}$ fraction (Fig. 5) representing mostly freeliving cells or small aggregates, suggesting that the cells stay in the aerobic environment (Mustafa et al. 2009). Indeed, a phylogenetic analysis conducted on the same water samples revealed that the collected samples from Mecklenburg lakes contained predom- 
inantly AAP species (Salka et al. 2011). Here, the only exception was the mostly anoxic Lake Haus (see Fig. 1C), where approximately $50 \%$ of all pufM clones were related to mostly anaerobic Rhodobacter species (Salka et al. 2011).

Waidner \& Kirchman (2007) reported that a large part of AAP bacteria in river estuaries were particle attached, and the percentage of AAP bacteria in the aggregates was higher than in the planktonic phase. In agreement with the previous reports from the Chesapeake and Delaware estuaries (Waidner \& Kirchman 2007, Cottrell et al. 2010) as well as from Mediterranean coastal habitats (Lami et al. 2009), in our study a large part (15 to $50 \%$, see Fig. 5) of the $\mathrm{BChl}$ a signal was also associated with larger $(>5 \mu \mathrm{m})$ particles. Based on microscopic observation, we assume that most of this signal originated from irregular aggregates, and organic debris colonized by the bacterial consortium. Monospecific clusters of only AAP cells or AAP cells colonizing phytoplankton cells were very rare. As shown previously, higher grazing pressure can keep the total AAP numbers low despite favorable growth conditions (Ferrera et al. 2011). A strong predation on AAP cells by mixotrophic ciliate Stentor amethystinus (>1000 ciliates $\mathrm{l}^{-1}$ ) was observed also in Lake Stechlin during our sampling in July 2009 (M. Mašín unpubl. data). High grazing pressure can also be responsible for relatively smaller AAP numbers and for a part of the observed AAP spatial and temporal variability. Furthermore, grazing may also result in a higher proportion of attached AAP as a protection strategy against grazing.

Crucially, it remains unknown whether and to what extent AAP bacteria benefit from possessing the photosynthetic apparatus. In his original paper, Kolber et al. (2000) speculated that the capacity to use light energy might be advantageous especially in well-illuminated oligotrophic systems. Later studies from various marine environments, however, demonstrated that high AAP numbers were found also in mesotrophic or eutrophic environments (Mašín et al. 2006, Waidner \& Kirchman 2007, Zhang and Jiao 2007). In the present study, we have found a general increase of total AAP abundance with the increasing trophic status (Figs. $3 \& 6 \mathrm{~A}$ ). However, when analyzing the relative AAP contribution to total bacteria in sampled lakes, there seems to be a trend with somewhat higher AAP percentages in oligotrophic lakes $(8.4 \pm 2.8 \%$; mean $\pm \mathrm{SD})$ compared to mesotrophic $(5.9 \pm 2.4 \%)$, eutrophic $(5.2 \pm 2.2 \%)$ or humic $(6.6 \pm$ $3.0 \%$ ) lakes (Fig. 6B). This result is in agreement with our previous data from Czech lakes; however, there was no significant relationship found between the relative percentage of AAP bacteria and total phosphorus or chlorophyll concentration. A part of the problem is that the trophic status depends on the total load of basic nutrients (in our case, mostly of phosphorus), whereas the concentration of available (reactive) nutrients might be seriously limiting even in lakes with overall high trophic status. Clearly, the relationship between AAP distribution and lake trophic status remains unsolved and needs further investigation.

In conclusion, our data confirm that AAP bacteria form a significant fraction of microbial communities in a number of freshwater lakes in northern Europe. Their abundance correlated with the total phosphorus content. Due to their rapid growth and efficient removal by grazing, AAP bacteria represent an important part of the food webs of the studied lakes.

Acknowledgements. The authors are indebted to K. Kalinowska and G. Brek for their great help with collecting samples from lakes of the Mazurian Lake District and Finnish lakes. R. Degebrodt and M. Sachtleben are thanked for technical assistance at the IGB-Neuglobsow. This research was enabled by projects GA ČR 206/07/P206 and Algatech (CZ.1.05/2.1.00/03.0110). This study was further supported by the bilateral Czech-German project DAAD, PPP-Tschechien 50016759/MEB100908 and the Leibniz foundation.

\section{LITERATURE CITED}

Allgaier M, Grossart HP (2006a) Seasonal dynamics and phylogenetic diversity of free-living and particle-associated bacterial communities in four lakes in northeastern Germany. Aquat Microb Ecol 45:115-128

Allgaier M, Grossart HP (2006b) Diversity and seasonal dynamics of Actinobacteria populations in four lakes in northeastern Germany. Appl Environ Microbiol 72: 3489-3497

> Chróst RJ, Siuda W (2006) Microbial production utilization and enzymatic degradation of organic matter in the upper trophogenic layer in the pelagial zone of lakes along a eutrophication gradient. Limnol Oceanogr 51: 749-762

Cottrell MT, Ras J, Kirchman DL (2010) Bacteriochlorophyll and community structure of aerobic anoxygenic phototrophic bacteria in a particle-rich estuary. ISME $\mathrm{J} 4$ : 945-954

Eiler A, Beier S, Säwström C, Karlsson J, Bertilsson S (2009) High ratio of bacteriochlorophyll biosynthesis genes to chlorophyll biosynthesis genes in bacteria of humic lakes. Appl Environ Microbiol 75:7221-7228

> Ferrera I, Gasol JM, Sebastián M, Hojerová E, Koblížek M (2011) Bacterial growth rates in the coastal Mediterranean: top-down and bottom up controls on the growth of different bacterioplankton groups. Appl Environ Microbiol 77:7451-7458 
Gich F, Overmann J (2006) Sandarakinorhabdus limnophila gen. nov., sp. nov., a novel bacteriochlorophyll a-containing, obligately aerobic bacterium isolated from freshwater lakes. Int J Syst Evol Microbiol 56:847-854

Harashima K, Shiba T, Totsuka T, Simidu U, Taga N (1978) Occurrence of bacteriochlorophyll $a$ in a strain of an aerobic heterotrophic bacterium. Agric Biol Chem 42: $1627-1628$

Hillbricht-Ilkowska A, Rybak J, Rzepecki M (2000) Ecohydrological research of lake-watershed relations in diversified landscape (Masurian Lakeland Poland). Ecol Eng 16:91-98

- Hutalle-Schmelzer K, Zwirnmann E, Krüger A, Grossart HP (2010) Enrichment and cultivation of pelagic bacteria from a humic lake using phenol and humic matter additions. FEMS Microbiol Ecol 72:58-73

Jiao N, Zhang Y, Zeng Y, Hong N, Liu R, Chen F, Wang P (2007) Distinct distribution pattern of abundance and diversity of aerobic anoxygenic phototrophic bacteria in the global ocean. Environ Microbiol 9:3091-3099

Koblížek M (2011) Role of photoheterotrophic bacteria in the marine carbon cycle. In: Jiao N, Azam F, Sanders S (eds) Microbial carbon pump in the ocean. Science/AAAS, Washington, DC, p 49-51

Koblížek M, Stoń-Egiert J, Sagan S, Kolber ZS (2005) Diel changes in bacteriochlorophyll a concentration suggest rapid bacterioplankton cycling in the Baltic Sea. FEMS Microbiol Ecol 51:353-361

Koblížek M, Mašín M, Ras J, Poulton AJ, Prášil O (2007) Rapid growth rates of aerobic anoxygenic phototrophs in the ocean. Environ Microbiol 9:2401-2406

Koblížek M, Mlčoušková J, Kolber Z, Kopecký J (2010) On the photosynthetic properties of marine bacterium COL2P belonging to Roseobacter clade. Arch Microbiol 192:41-49

Kolber ZS, Van Dover CL, Niederman RA, Falkowski PG (2000) Bacterial photosynthesis in surface waters of the open ocean. Nature 407:177-179

Kolber ZS, Plumley FG, Lang AS, Beatty JT and others (2001) Contribution of aerobic photoheterotrophic bacteria to the carbon cycle in the ocean. Science 292: 2492-2495

Koroleff F (1976) Determination of phosphorus. In: Grasshoff $\mathrm{K}$ (ed) Methods in seawater analysis. Verlag Chemie, Weinheim, p 125-131

> Koschel R (1995) Manipulation of whole-lake ecosystems and long-term limnological observations in the Brandenburg-Mecklenburg Lake District, Germany. Int Rev Gesamten Hydrobiol 80:507-518

- Lami R, Čuperová Z, Ras J, Lebaron P, Koblížek M (2009) Distribution of free-living and particle-attached aerobic anoxygenic phototrophic bacteria in marine environments. Aquat Microb Ecol 55:31-38

Lorenzen CJ (1967) Determination of chlorophyll and phaeopigments: spectrophotometric equations. Limnol Oceanogr 12:343-346

Martinez-Garcia M, Swan BK, Poulton NJ, Gomez ML, Masland D, Sieracki ME, Stepanauskas R (2012) Highthroughput single-cell sequencing identifies photo-

Editorial responsibility: Paul del Giorgio,

Montréal, Canada heterotrophs and chemoautotrophs in freshwater bacterioplankton. ISME J 6:113-123

- Mašín M, Zdun A, Stoń-Egiert J, Nausch M, Labrenz M, Moulisová V, Kobližek M (2006) Seasonal changes and diversity of aerobic anoxygenic phototrophs in the Baltic Sea. Aquat Microb Ecol 45:247-254

> Mašín M, Nedoma J, Pechar L, Koblížek M (2008) Distribution of aerobic anoxygenic phototrophs in temperate freshwater systems. Environ Microbiol 10:1988-1996

> Medová H, Boldareva E, Hrouzek P, Borzenko S and others (2011) High abundances of aerobic anoxygenic phototrophs in saline steppe lakes. FEMS Microbiol Ecol 76: 393-400

Mustafa IH, Ibrahim G, Elkamel A, Elahwany AH (2009) Modeling of activated sludge floc characteristics. Am J Environ Sci 5:69-79

> Page KA, Connon SA, Giovannoni SJ (2004) Representative freshwater bacterioplankton isolated from Crater Lake, Oregon. Appl Environ Microbiol 70:6542-6550

> Salka I, Moulisová V, Koblížek M, Jost G, Jürgens K, Labrenz M (2008) Abundance depth distribution and composition of aerobic bacteriochlorophyll a-producing bacteria in four basins of the central Baltic Sea. Appl Environ Microbiol 74:4398-4404

Salka I, Čuperová Z, Mašín M, Koblížek M, Grossart HP (2011) Rhodoferax-related pufM gene cluster dominates the aerobic anoxygenic phototrophic communities in German freshwater lakes. Environ Microbiol 13: 2865-2875

Shiba T, Simidu U, Taga N (1979) Distribution of aerobic bacteria which contain bacteriochlorophyll a. Appl Environ Microbiol 38:43-45

- Sieracki ME, Gilg IC, Thier EC, Poulton NJ, Goericke R (2006) Distribution of planktonic aerobic anoxygenic photoheterotrophic bacteria in the northwest Atlantic. Limnol Oceanogr 51:38-46

Waidner LA, Kirchman DL (2005) Aerobic anoxygenic photosynthesis genes and operons in uncultured bacteria in the Delaware River. Environ Microbiol 7: 1896-1908

- Waidner LA, Kirchman DL (2007) Aerobic anoxygenic phototrophic bacteria attached to particles in turbid waters of the Delaware and Chesapeake estuaries. Appl Environ Microbiol 73:3936-3944

Wetzel RG, Likens GE (1991) Limnological analyses, 2nd edn. Springer-Verlag, New York, NY

Yurkov VV, Csotonyi JT (2009) New light on aerobic anoxygenic phototrophs. In: Hunter CN, Daldal F, Thurnauer MC, Beaty JT (eds) The purple phototrophic bacteria. Springer Verlag, Dordrecht, p 31-55

Yurkov VV, Gorlenko VM (1990) Erythrobacter sibiricus, sp. nov., a new freshwater aerobic species containing bacteriochlorophyll a. Microbiology 59:120-126

Yurkov VV, Gorlenko VM (1992) New species of aerobic bacteria from the genus Erythromicrobium containing bacteriochlorophyll a. Microbiology 61:248-255

Zhang Y, Jiao N (2007) Dynamics of aerobic anoxygenic phototrophic bacteria in the East China Sea. FEMS Microbiol Ecol 61:459-469

Submitted: February 7, 2011; Accepted: January 23, 2012

Proofs received from author(s): March 20, 2012 